[ARTICLE 19,-EXTRACTED FROM THE BULLETIN OF THE U. S. FISH COMMISSION FOR 1894. Pages 289 to 314 .]

\title{
FEEDING AND REARING FISHES, PARTICULARLY TROUT, UNDER DOMESTICATION.
}

BY

WILLIAM F. PAGE.

WASHINGTON :

GOVERNMENT PRINTING OFFICE. 1895 . 


\section{FEEDING AND REARING FISHES, PARTICULARLY TROUT, UNDER DOMESTICATION.}

WILLIAM F. PAGE.

is

WASHINGTON :

GOVERNMENT PRINTING OFFICF.

1895 . 



\section{9.-FELDING AND REARING FISHES, PARTICULARLY TROUT, UNIDER DOMESTICATION.}

By WILLIAM F. PAGE,

Superintendent of Uniled States Fish Commission Station at Neosho, Missouri.

\section{ARTIFICIAL FOOD.}

In the summer of 1893 I presented a paper at the Chicago meeting of the American Fisheries Society under the title: Plant Yearlings Where Needed. A portion of the paper contained a summary of some studies which I had made on feeding and rearing fishes. The present paper is an elaboration of that summary by adding the results of further study and investigation.

To the fish-culturist striving to improve methods and results the importance of the question of fish food ean searcely be exaggerated. Aside from the interest on the cost of the plant and pay of the necessary employés, it is the principal fixed eharge, and in most cases the only item of expense capable of reduction, or, what amounts to the same thing, the most promising field for obtaining better results for the outlay.

$I$ address myself particularly to those fish-culturists who are engaged in rearing fishes to be sold for food, and to those who see the necessity for planting large fish in certain waters intended to be stocked. The paper will have little interest for those who dispose of their fish as fry. To the former class the data, if not the deductions, must possess some value.

Nowhere in the literature of fish-eulture obtainable at the general book stores can the prospective investor find an answer to the natural question, How much will it cost to raise a pound of trout? unless we except the statements made in the concluding chapter of Domesticated Trout, a part of which was written twenty-two years ago, and the remainder in 1890 , statements which, I think, Mr. Stone would not care to guarantee to-day.* In $1864 \mathrm{Mr}$. Francis Francis wrote:

Donbtless some kinds of food agree with them [trout] far better than others. But we know very little on this branch of the subject. It is dreamland to us, with very little ascertained waking reality. Few experiments of any note have been tried in the feeding of fishes, this being as yet almost untrodden ground.

This remark is as true to-day as when written, thirty years ago, and stands as a monument to the want of progress among American fish-eulturists. I say American fish-culturists, for fortunately the Europeans have progressed in this direction. Because over two decades ago a fish-culturist, groping in the dim light of a elosely shuttered house illuminated by a single bull's-eye lantern, killed his trout with a diet of milk curd, and another expert, with as much (or as little) light in the house and on

*In the Transactions of the American Fisheries Society for 1892, Mr. F. N. Clark presents some calculations on the cost of raising yearling fish, and in the United States Fish Commission Bulletin for 1893, page 228, Mr. C. G. Atkins gives some similar data; but neither of them reduces the cost to pounds of fish, without which, for the purposes of this discussion, the data possess little or no value.

$$
\text { F. C. B. } 1894-19
$$$$
289
$$ 
the subject, killed his fry with the yolk of hens" eggs, the law was laid down, "You must not use curd or hens' eggs for fish food," and these two really valuable articles were placed on the blacklist. Unfortunately, with all our vaunt of being the most advanced of the world's nations in fish-culture, we are so conservative that it rarely happens that an article which once finds itself on the list of prohibited foods receives a second trial. As a matter of fact, one of the best experts in the world to-day, one who makes the business pay a handsome return on the money invested, Sir James Maitland, of Scotland, as far back as 1878 was using fifteen dozens of hens' eggs daily. Again, one of the State fish commissions west of the Mississippi River depends largely upon curd as a trout food.* Their work will be shown to compare favorably with that of other places where these cheap articles are interdicted.

Another article proseribed by one of the books on fish-culture is to-day almost the sole food of one of the best-paying private hatcheries in America. These instances are stated to show that the rules laid down in the text-books are not in all cases reliable, having been too frequently drawn from a single illy conducted experiment. Scarcely any of the writers have anything to say on the really important question, How much food is required to produce a given result? Nowhere in the English books are data and rules given which would enable one to calculate with any degree of exactness the amount of food needed during a given period for a given number of fish. One important use of such knowledge would be the calculating of a periodic supply of food for some hatchery situated away from the lines of easy and cheap transportation. Should the feasibility be demonstrated of the preparation, at the base of cheap supply, of an artificial food to be preserved and shipped in large quantities by freight to off-lying hatcheries, the question would naturally arise, How much will be needed during the next six or twelve months? The early experimentalists contented themselves with saying that such and such things made safe, cheap, and economical foods (in nearly every case having reference to liver, heart, and lungs of animals), and that such and such were poisonous to the fish, and quietly ignored the question of definite quantities.

The fact is that there is searcely an article in the entire gamnt from curd to horseflesh that may not be fed to trout with perfect safety. The questions are, or should be: What amount per day of a given article will be needed to produce a pound of trout within a given time? Is this amount of food beneficial or harmful to the correct or normal development of the fish? If harmful, can it be rendered harmless by the admixture of other foods? And, finally: Can the grower for the market find a profit?

In my Chicago paper it was stated:

There are among fishes, in common with other animals, several dietaries, some followed from a matter of choice, some from necessity, and others from ignorance on the part of the attendant. They may, for convenience, be thus classified: First, bare subsistence diet, merely sustaining life and resulting in stunted, deformed fish, or starvation; second, healthy diet, promoting normal growth and development; third, fattening diet, fitting for heaviest marletable weight; and, fourth, overfattening diet, causing a temporary or permanent suppression of the functions of the reproductive organs, a partial or total destruction of the eyes, and inflammation of the intestines, frequently resulting in death.

A considerable percentage of American fish-culturists are to-day confining their stock to the first diet, either in quantity or quality of food, and are yearly producing stunted or half-starved fry which, by courtesy, are called yearlings. Dismayed by their own early experiences and those of the first experimentalists in feeding fishes, they have not only stricken article after article from the list of available foods, but

"Practical Trout Culture, Dr. Slack, page 123: "Curd is absolutely poisonous." 
have reduced the quantity below the point of healthy development. One of the early writers has said, with every appearance of correctness, that if the fry are starved in infancy they become stunted, the bones harden, and afterwards no amount of feeding will cause them to expand sufficiently to permit of growth. Unquestionably, it is at this stage in the rearing of fishes (the earliest feeding of the fry) that the greatest amount of damage is possible and the most lasting hurt frequently done. It is the most difficult stage in feeding and rearing, beeause it is at this point that intelligence and fidelity are needed more than at any other time.

In the first feeding of fry it is not practicable to weigh the fry or their food so as to instruct the caretaker as to the allowance of food; though after the fry have been taking food for some little time it is possible to determine their weight, but it is scarcely probable that any except the most careful experimentalists will ever expend the time and labor necessary. It is not likely that any better method for this determination will be devised than that of Mr. Charles G. Atkins, of the U. S. Fish Commission. His method is as follows:

The fish are first gathered in a fine, soft bag net, commonly one made of cheese cloth, and from this, hanging meanwhile in the water, yet so that the fish can not escape, they are dipped ont a few at a time in a small dipper or cup, counted, and placed in a pail of water or some other receptacle. This counting is generally preliminary to weighing, and in this case the fish after counting are placed in another bag net, in which they are lowered several hundred at a time into a pail of water, which has been previously weighed, and the increase noted. With care to avoid transferring to the weighing pail any surplus of water, this is a correct method and very easy and safe for the fish. - (Bulletin of the U. S. Fish Commission, 1893, p. 227.)

Mr. Atkins does not say so, but it would seem that he must deduct from the increased weight the weight of the wet bag net immersed in the weighing pail.

Only judgment, experience, fidelity, and watchfulness on the part of the attendant charged with the feeding will be found to answer at the time when the fish first commence to take food; and unless these qualifications are employed the fish are either fed to death or starved. Some of the rules for feeding young fry would be laughable if it were not for the memory of the helplessness of the fish. A rule at one hatchery is to give them all they will hold; another acquaintance says keep them hungry all the time. There are few happy mediums in practice. Years ago the idea was disseminated that any elever youth of ordinary capacity could safely be intrusted with the care and feeding of fishes. Unfortunately the idea is not yet entirely eradicated. They are short-sighted managers, blind to the principles of protection of animals from cruelty, who leave this most important branch of the work in the hands of any except the patient, intelligeut, skilled workman.

Not all cases of semistarvation and stunting have resulted from the causes mentioned-ignorance or fear on the part of the attendant. Cases have fallen under my observation where, from various causes, the desired food, either as to kind or quality, was not obtainable. Again, some fishes, partieularly brook-trout fry, will persistently decline the most dainty and delicately prepared foods. My own opinion is that when a lot of fry is found acting in this manner the best thing the culturist ean do for himself is to get rid of them at an early day. They will never make fine fish. * Several reasons have been advanced to account for this peculiarity on the

* In this connection the question presents itself: May we not from this find a possible reason why in certain streams, presenting a fair abundance of food, we never find trout above tingerlings in size. I, of conrse, suppose that in nature, as well as in artificial fish-culture, there are cases where the young, from some cause, will not eat, and it is more than probable that in many lots of fish hatched naturally a large percentage never find any food, or find it too late to prevent or arrest the stunting process. Once stunted, always stunted. 
part of certain lots of trout, none of which are entirely accoptable. One writer* asserts that at the time of the absorption of the sac the fry rises in search of natural food, and if he does not find it he is compelled to take the artificial food prepared for him, and the difficulty of adapting his stomach to this food results in a loss which varies from 50 to 75 per cent.

Another fish-culturist says that they fail to assimilate the artificial food and die. In passing, I hope to be pardoned for asking if the trout fry in the feeding troughs offered artificial food when nature demands an aliment, even granting for argument that they can not always assimilate it, are not in better position to fight the battle of life than the trout fry in the streams, either hatched or planted there, where they too frequently find an entire absence of food, for we know that streams are as frequently barren of natural food for trout fry as the streets of cities are barren of food for children. They live and reach a certain phase of maturity, but the product too often falls short of expectations.

At one large establishment where the yearling fish have for a number of years been abnormally small the trouble is thought to be due to prevailing low temperature of water. This, in a measure, may be true, for it is a generally accepted opinion that trout will not readily take their food on cold and cloudy days, and it is not unreasonable to suppose that the same canse wonld prevail in water of a constantly low temperature. My own observations lead me to believe that, outside of the spawning season, properly trained trout will eat as greedily during a snowstorm as during fair weather.

To whatever cause due, it must be admitted by every candid and impartial observer that thousands of trout are annually raised which in size fall short of a commensurate return for the time, interest, and money expended. I hope to show that a partial correction is possible by the use of an adequate quantity of proper food. Private fish-culturists, selling yearling fish at so many dollars per thousand, are more than any others interested in making this correction. Information is begiuning to be disseminated on this subject, and the purchaser, who a few years since was willing to pay fancy prices for that most meaningless and illy defined of all salable products-yearling trout-is now commencing to ask, "Of what size are the fish " It seems to me that it would be rational and fairer to all parties to establish a weight per thousand and grade the prices up or down as the weight rose above or fell below the standard.

The importance of making such correction as above suggested is apparent, for if at times we are stocking streams with stunted fish we are antagonizing one of the hopes and claims of fish-culture, namely, the improvement of existing species. I care not how carefully the breeders may be selected, how minutely all the essentials of impregnating, hatching, and transporting receive attention, the resulting adult fish will never be of large size and fine quality unless the fry have been properly fed; and it is probable that if these fry have been stunted their progeny will be stunted. The progressive and enlightened cattle-breeder looks closely to it that those individuals which are to perpetuate his herd have received proper feeding and acquired full and normal development; and if by chance a runt is among the herd, it is set apart from the breeders. For the same reason we should not allow stunted fishes to enter into the brood stock or into streams.

Against the danger of under feeding there should be little cause to warn the culturist engaged in growing for the market. But because I have known such cases, 
the warning is distinctly given to the private fish-culturist. The greatest draw back against raising large tront in a given time (possibly surpassed by an improper selection of breeders) is an improperly prepared food given in starvation rations to the fry. "As the animal is, so to speak, made during its early age, and as during this period its assimilating organs aequire their strength and their power of absorption, a young fish which is insufficiently fed not only grows very slowly, but will never become a fine fish." * Time was, and unfortumately is yet with too many, that cannibalism was the only danger feared from fry on short rations. Cannibalism was a very good bugbear, but the true danger does not lie there, as it is always capable of correc. tion in a short time.

The discussion of the second and third diets mentioned will be passed over for the present and we will proceed to look at some of the ill effects of the fourth, overfattening diet, "causing a temporary or permanent suppression of the reproductive organs, a partial or total destruetion of the eyes, and inflammation of the intestines, frequently resulting in death." Nearly every fish-culturist of experience has seen the two latter evils, "pop-eyes" and "inflamed intestines;" whilst many have observed, without knowing the cause, the retardation of the genital organs of the fishes. It seems fairly probable that the canses known to affect the breeding of other animals will in like manner influence the breeding of fishes. It is a recognized principle among stock-breeders that an overrapid accumulation of fat is followed by partial or total sterility, just as conversely a removal of the genital organs is always followed by a rapid accumulation of flesh. It would seem that the two processes are intimately connected, and that an excess in either direction is at the expense of the other. The complaint has not infrequently been made: "My fish grew finely, attained a remarkable growth, and I fully expected a large number of eggs this season, but got very few." It rarely or never occurs to such complainants that the want of eggs was due to the exceptionally fine growth. I have in mind a hatchery where the growth of brook trout was such that many of them lost their eyes. Eggs were obtained in fair quantity, but they were of such low degree of vitality that the season was counted a failure. When these fish were marketed their quality was graded low. More than twenty years previously Dr. Slack had noted a similar oceurrence. In his book (Practical Trout Culture, p. 121) he recounts the following:

A wealthy gentleman of a neighboring State constructed a well-appointed fish farm, with wellstocked ponds. To his surprise, during the spawning season but few eggs could be obtained and but a small percentage of these conjd be impregnated. We were consulted in regard to the matter, and our first look at his fishes showed 118 plainly the cause of the trouble. The fishes were enormons, the bodies greatly swelled, the whole cavity of the abdomen being filled with layers of fat. It appeared that the proprietor had for over a year fed them twice a day all they could eat, and the result was, as might have been expected, barren and unhealthy fish.

If ever artificially reared trout sell on a parity with wild trout-and there is no reason why they can not be mate to do so-it will not be the overfed, pop-eyed, liverreeking fish, which will produce the result. The danger of overfeeding is just as distinct and as much to be avoided as that of underfeeding, though obviously the evil effects will be less lasting and more restricted in results.

Let ns now turn to the second classitication, "healthy diet, promoting normal growth and development." By healthy diet I mean not only the proper amount of food per day, but a food composed of proper constituents. It has been before inti. 
mated that the writers on fish-culture have been vague in clealing with this subject. A few quotations will serve to make this point clear:

This quantity varies with the season, the quality, the quantity, and temperature of the water, and other circumstances, aud can not be stated definitely.-(Domesticatel Tront, Livingston Stone,p. 236.)

Under favorable cireumstances 5 pounds of meat food may be considered an equivalent for a pound of tront growth, with 2 and 3 year olds. For any given quantity of 2 or 3 year olds 1 per cent of their weight may be regarded as an adequate average daily ration the year round. Two and three year olds will double their weight annually, and can be made to do so in the six months from May to September by extre care and feeding.-(Domesticated Trout, p. 265.)

As to the quantity of food necessary for a given number of trout. This is difficult to gire exactly, as it will vary with the size of the fish and the season of the year, more being required in moderate weather than when it is very hot or cold. For 1,000 three year-olds, about 5 pounds of liver or lights per day.-(Trout Culture, Seth Green, p. 51.)

When six months old a bowlfui of eurd, diluted with water, will answer for 1,000 trout fry.(Trout Culture, Seth Green, p. 38.)

Since our stock of fishes attained its present size we have never been able to obtain as large a supply of food as we would desire; yet we find that our stock fishes, weighing in the aggregate about a ton (2,000 pounds), thrive upon 50 pounds of lights a week, fed them in equal proportious on alternate days. As an average 50,000 young will require, when 6 months old and well supplied with maggots, about a pound of chopped heart thrice weekly, though the amount varies greatly.-(Practical Trout Culture, Dr, J. H. Slack, pp. 121 and 125.)

The quantity of food required is also large (for 2-year-old tront). Three pailfuls of ehopped horse are given daily to pond 15 , which yields from 20,000 to 22,000 each season. The food is measured, not weighed, but each pail holds 14 pounds.-(History of Howietoun, Sir James Maitland, pp. 73 and 74.)

When tront are raised in ponds of the dimensions $I$ have giren it is evident that little or no dependence is to be placed on natural feed, such as flies and their larva. Hence the necessity of providing eurds or liver and lungs of animals, at prices that will not canse too great an expenditure for the value of the crop. I have found that the curd from the milk of oue cow, which gave 14 quarts, would feed bountifully 1,000 or 1,200 trout averaging five-eighths or three-ruarters of a pound, the smallest being 7 inches long and the largest from 2 to 3 pounds in weight.-(American Fish Culture, Thaddeus Norris, p. 74.)

These quotations, carefully seleeted as the expressions of the five most generally read English writers on fish-culture, ${ }^{*}$ show how little definite and aecurate information is recorded on the vital question of what should constitute a proper ration for a given number of trout. Sometimes the number of fish is stated, sometimes their age, in one instance the approximate weight is given, and only one English writer has had the courage to approach scientifie accuracy. But, alas! His formula is made to apply only to fish 2 and 3 years old. The fry and the fish more than 3 years old are not provided for.

The amount of food necessary for the maintenance in good health of a given lot of fish must, as with any other animals, be in direct ratio to their weight, not their age.

* From writers of other nationalities the following quotations may be acceptable:

By experiments M. Lugrin has ascertained that a basin * * may contain 20,000 voung fish from 8 to 12 months old, or 3,000 two-year-old trout having an average weight of 250 grams ( $(1,1$, or a little more than one-half pound). These 20,000 young fish, or 3 , 0 o tront, consume about 22 pounds of small shrimps per day.-(The Piscicnltural establishmentat Gremaz, Franee; by C. Raveret-Wattel, Bulletin U. S. Fish Commission, 1887, p. 209 et seq.)

At Howietonn it is on the weight (one-fiftieth of the living weight) that is determined the food to begiven, a method which appears more scientific and at the same time mort practical than that of feeding them withont regard to age or development.- Notes of M. Wesprés, proprietor of the fishcultural establishment at Nantenil-eu-Vallee, France.) [I havenot been able to find this formula of one-fiftieth of the living weight anywhere in the History of Howietoun, and I suppose that M. Després mist have received the information privately. I am fully in accord with M. Després in his criticism on the value of this formula.] 
To state that 20,000 fish require three buckets of food per diem, without stating the weight of the fisl, is insuflicient.

One of the first things to impress itself upon the attention of the student of this question is the wille and almost unaccountable variation in the size and weight acruired by fishes of the same species under different hyrlrographic and climatologic conditions. In some instances this variation amounts to 700 per cent. Compare the weights of yearling tront raised 1 Coloralo and Missouri. Who wonld say that 1,000 of the Nissouri trout should be restricted to the same daily rations as a like number of like fish in Coloradn? Elsewhere I have said that the Colorado trout cond not consume the allowance of the Ozark (Missouri) trout, and that the Ozark trout would stuut or starve on the Colorallo allowance. Better results will be obtained when fish-culturists realize that fishes must be properly and plentifully fed in their infaney aud that their allowance of food, regariless of age, must be in constantly ascending ratio with their inereasing weight.

In the first study of this question I early found the lack of definite data in the English writings. Correspondence was instituted to ascertain the general practice. For couvenience of comparison and study a condensed tabular statement of the replies received is here presented:

Food and growth of trout.

\begin{tabular}{|c|c|c|c|c|c|c|c|c|c|c|c|}
\hline \multirow[b]{2}{*}{$\begin{array}{l}\text { Name and locatinn of } \\
\text { establishment. }\end{array}$} & \multirow[b]{2}{*}{$\begin{array}{l}\text { Elera- } \\
\text { tion } \\
\text { above } \\
\text { sea } \\
\text { level. } \\
\end{array}$} & \multirow[b]{2}{*}{$\begin{array}{c}\text { Mran } \\
\text { anzual } \\
\text { tem. } \\
\text { pera. } \\
\text { ture of } \\
\text { witter. }\end{array}$} & \multirow[b]{2}{*}{\begin{tabular}{|} 
A rerage \\
laily ra- \\
tions, in \\
pwumbs \\
per 1,000 \\
yearling \\
trout.
\end{tabular}} & \multirow[b]{2}{*}{$\begin{array}{l}\text { Character of } \\
\text { fomd. }\end{array}$} & \multirow[b]{2}{*}{$\begin{array}{l}\text { Natural food } \\
\text { present in } \\
\text { ponds. }\end{array}$} & \multirow[b]{2}{*}{$\begin{array}{l}\text { Length } \\
\text { of aver. } \\
\text { age year- } \\
\text { ling } \\
\text { trout. }\end{array}$} & \multicolumn{5}{|c|}{$\begin{array}{l}\text { Weight per } 1,000 \text { arerage } \\
\text { yearlings, in pounds. }\end{array}$} \\
\hline & & & & & & & $\frac{3}{\circ}$ & $\frac{3}{3}$ & 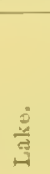 & $\begin{array}{l}\frac{5}{\tilde{N}} \\
5 \\
5\end{array}$ & 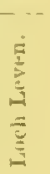 \\
\hline Solmar, Scot & 15 & ${ }_{50}^{2 F}$. & & & & $\begin{array}{l}\text { Inches. } \\
2.5 \text { to } 6\end{array}$ & & Not & ests 1 & aade. & \\
\hline 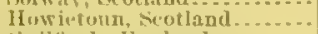 & 300 & & 66 & .010 & do. & 3.5 & & test & $3 \mathrm{mad}$ & & \\
\hline Td, Eng & & & r.xy $\sin \mid 1$ & do & Abundan & 4 to 10 & 50 & & & 50 & 50 \\
\hline aslemere, Eugland & 200 & $49-56$ & $\ldots$... & $d \theta$ & ..... do & 4 to 10 & ii) & & & 5 & ill \\
\hline vero, Mexico. & 7. 600 & 37 & 4 & do & & 6 to 7 & & 114 & & & \\
\hline Condesa, Mexico & 6,500 & $68-70$ & $\cdots$ & do & No.. & 7 to 8 & 1 & 160 & & & \\
\hline Could Spriag Ponds, N. HI. & 500 & $35-76$ & 35 & a'18 reg. & None.... & $\begin{array}{l}6 \text { to } 7 \\
7 \text { to } 10\end{array}$ & 1.60 & & & & \\
\hline $\begin{array}{l}\text { Troutdale Farm, drk .... } \\
\text { Wjllow Brook, Jinn .... }\end{array}$ & 600 & $\begin{array}{l}59.5 \\
46.5\end{array}$ & 10 & $\begin{array}{l}\text { tanim 1 veg. } \\
\text { Animal.... }\end{array}$ & $\begin{array}{l}\text { Amindant } \\
\text {.....do... }\end{array}$ & 7 to 10 & 7.1 & $=0$ & 1.01 & & \\
\hline Annin's Hatcherv, Caledo- & 690 & & & ..... do. & Some.... & 3.25 & $1 i$ & $11 i$ & +21 & +15 & \\
\hline nin, N. Tolong, Plymouth, Mass. & & & 7.5 & do & Im'nse qqu'n’ty & 6 & $: 90$ & & & & \\
\hline State Iatcher乡 Nerada.... & 4,660 & 45 & & & Yes............ & 6 & & Not $t$ & 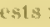 & made. & \\
\hline State Hatchery, Nebraska. & 1,100 & 50 & .5 & do & Limiter .... & 4.5 & $\begin{array}{l}50 \\
70\end{array}$ & 50 & & 50 & \\
\hline $\begin{array}{l}\text { Duluth station, U.S. F.C. } \\
\text { Lendrillo Station U.S.F. C. }\end{array}$ & $\begin{array}{r}602 \\
9,640\end{array}$ & 36. & .12 & . do & Considerable. & & 10 & 80 & & & \\
\hline Northville Station, U.S.F.C & 6100 & 14.: & .11 & do. & Scarce........ & 4 to 6 & $\$$ (fi) & $\$ 80$ & ... & 540 & \\
\hline Wytheville Stat' $n$, U.S.F.C. & 2,300 & 53 & .47 & ...do. & ... do . & 4. 5 & & 60 & & & \\
\hline Neosho Station, O.S. F. C. & 1,041 & & 1.87 & | & . . . . do ....... & & 75 & 51.8 & & & \\
\hline
\end{tabular}

* This weight was for fish 15 months old. M y experiments in tho spring of 1833 demonstratesl that ratinbow trout increase their weight enormously in the fourteenth and fiftecnth months. In proportion to the increase at Neusho the Troutdale (Mammoth Spring) trout, at 1 year old probably weighed 82.27 pounils per 1,000 fisls.

t Mr. Anuin sars: "I hare been rery careful that my answers have been correct, aul not magnified."

? These answers are griven as of May 1. I should say that the fish wero yearlings past, and, jul ging from the length of the tish, rery highly fed.

s Determined by the weights of apecimen fish fumished to be cast for the Worhl's Fair at Chicago. Fish furnished by the Neos ho station for the same purpose ran 330 pounds for brook, 200 pounds for Von Behr, and 140 pounds for rainbow trout (per 1,000 yearing tish). 
The difference in locality, elevation above the sea, and mean annual temperature of the water at the hatcheries is quite varied, hut not more so than the daily rations given. As for the results-the weight of the yearling lish-the data as given do not arlmit of a too close comparison, some of the fish having been weighed at 10 months old and others at 15 months old.

However, a sturly of the table does show that there is not only a rlecided lack of larmony between the practice or methods of feeding followed at the various establishments, but that some are giving an inadequate guantity of food and others are feeding far in excess of the needs. For instance: Leadville Station gives but 2 ounces of animal food jer day per 1,000 yearling trout, while the Willow Brook Hatchery, of the Minnesota Fish Commission, gives eighty times as much to the same number of fish. The quantity of food used at the Leadville station is the smallest for which I have any return, and it is not surprising to fimd that the fish grown there are sualler than at any other hatehery in the United States. The next smallest is the Howietoun Fishery, of Scotlaud, where the ration is but two-thirls of a pound and the weight of 1,000 yearliug fish (Loch Leven tront) but 10 poumds.

When the very small size of the fish produced at Leadville first came under my notice I was of the opinion that the extreme altitude of the place might in some way (possibly by reason of the low temperature of the water consequent upon such great elevation) be a controlling factor in prolucing such a slow growth. So firmly was this idea fixel, that when the returns from the Mexican hatcheries were received I requested a retesting of the weights. Not only was the weight as first given corroborated, but a sample of the food used was furnished. In that sample of food, "mosquitte" (Corian femoruta) was found the secret. It was a correct food, unfortumately at present beyond the reach of American fish-culturists.

Seeing, then, that the laws of the text-books and the general practice are so variable, vagne, and unsatisfactory, let us see what may be determined by analogous reasoning from the established laws of dieteties for other animals.

Before entering upon this branch of the subject the reader is requested to beat in mind that fish are cold-blooded and will never need-in fact, would be overburdeued with-as large a proportion of heat-producing foods as are necded by the warm-blooded animals. Being cold-blooded, they have no body temperature to maintain, and so do not require in so large a degree the rich bydrates of carbon neeled by the warmblooded animals. A gain, in small ponds, where the very largest per cent of the foor is supplied artiticially, the rork of the fishes in procuring a livelihood is reducer to a minimum, and this will also be found a factor in determining the character of the foorl to be supplied.

Animals for which laws of dieteties have been established most nearly resembling the condition of fishes under domestication are cattle and men not at work. But no perfect parallel can be drawn between these classes on account of the body heat to be maintained on the one hand and its absence on the other. It seems that the average man, passive or at lightest work, requires, accorting to the various authorities, solid substances rauging from 20 to 4 tounces per day** Assuning the average man to weigh 130 pounds, the average of the allowance of the anthorities would be 1.1 per cent of the weight of the man. Dr. M. (\%. Ellzey, formerly jrofessor of agriculture at

"Billings's National Melical Dictionary, p. xxxix; Flint's Text-Book IInman Physiology, pu. 191, 192; Marshall's Outlines I'hysiology, p. 849. 
the Virginia $\Lambda$ grieultural and Mechanical College, is my anthority for saying that "about $1 \frac{1}{2}$ per cent dry food substances of the live weight is reckoned good keep for mature live stock."

It will be noticed that these allowances are for dry substances only. In an attempt to make a comparison between the food allowances for men and cattle and fishes the liquid substances have purposely been omitted. This is impossible of calenlation for the fishes. It will vary constantly with the character of the water, the soil over which it drains, and the season of the year. It may ronghly be assumed that the sustaining elements of the coffee, tea, milk, etc., entering into the food of the rarm-blooded animals is replaced or compensated for by the insect life present to a greater or less extent in or over most waters.

A study of the foregoing table and quotations giving the feeding methods followed at the varions fish-cultural establishments shows that the average of the food allowance is $6 \frac{1}{2}$ per cent of the weight of the tront. Last year $\mathbf{I}$ expressel the opinion that this allowance was in excess of the requirements. This judgment was possibly hasty, for it is to be noticed that in every instance the amounts are for wet fonds; that is, for liver, meat, curd, etc., in a more or less moist condition. The limited data at my command shows that 1 pound of liver contains 24 per cent of dry substance; 1 pound of horseflesh contains 23 per cent of dry substance, and 1 pound of curd contains 45 per cent of dry substance. From tests I find that 1 pound of mush made from ship. stuif, or shorts, contains 28 per cent of dry substance. Hence we rould liave as the average 213 per cent of dry substance given to tish as against $1 \frac{1}{2}$ per cent allowed eattle and men not at work. I think it will be admitted that this is too much. Not only is it contrary to analogy, but the experience of the Neosho Station has proven, to my satisfaction at least, that it is in excess of all requirements. In the year which gave us the highest degree of satisfaction the food allowance was 3 per cent wet substances, or 0.75 per cent dry substances. The tront at one year old in that season attained a lengtin of 6 inches and a reight of 51.86 pounds per 1,000 fish. On page 300 will be found the schedule of the food allowance for these fish chring each month of the year reduced to a daily allowance per 1,000 fish.

From the foregoing, and from other observations, I am of the opinion that 1 per cent of the live weight per day of dry substances will be found ample for tront, and that an amount much in excess of this, would be prejudicial to the development of the fish. But it must not be supposed that this allowance of any or all substances will be found to produce the desired result. As before intimated, the contrary will sometimes happen. Man could exist but a short time ou $1 \frac{1}{2}$ per cent of his weight on bread or meat alone. Not only this, but it has been pointed out that all foorl substances vary, in the quality of their constitnents, with the soil and season. No matter how perfect the premises and how careful the reasoning, safe laws of dietetics, for man or fish, will be found to require a great degree oi elasticity.

Certain couditions are necessary to make an artificial food generaliy acceptable. The supply must be convenient and certain; the cost must be snch as not to entail too great an expenditure for the valne of the crop of fish; it shonld be a substance of easy and rapid preparation, and, above all, the chemical composition, or proportion of nitrogenous and nonnitrogenous constituents, should be in accordance with the requirements of the fishes to be fed. In determining the food to be used at any hatchery all of these factors unst be considered in connection with the eonditions of 
the local market. The one element of food which has most generally been found to fill these conditions is liver. It was probably the most fortunate accilent in the history of fish-culture that the circumstances of the first three conditions forced the attention of the early culturists to liver. Its adoption may be viewed in the light of a lucky accident, for in those dass only the first three conditions were recognized, and the fourth and most important condition, the proper combination of the elements with a view to the requirements, was not considered by the fish-culturist. To-day, unfortunately, it is but slightly understood. In substantiation of the view of the value of liver the reader is referred to Prof. E. Wolly's table of percentage of nutritive snbstances used as fish food.* From this table it appears that the chemical compo sition of liver (and hearts, lungs, and brains of oxen) more nearly approximates that of insects and their Iarve than does any other article of animal substance which has yet come into use.

In Nicklas's Pond Culture the study of the food for earp is detailed fully. Nicklas dednces the formula that-

The most favoralo proportion of nutritive substances in earp food is Nh: Nfr : : $1: 0.5$ (or 0.6 ), and that consegueutly food containiug a gool denl of nitrogen is the best and most profitalele for carp. The most suitable articles for foud, therefore, are blood, horsellesh, fish guano, curds, meat dried and gronul fine, refinse from slangliterhonses, etc. Ill these, howerer, require to be mixed with. other articles of food containing less nitrogen, so as to restore the proper proportion of wutritite substances. On the whole the fool for the carp will have to be mixed very much on the same principle as that for cattle and other domestic animals.

The italies in this quotation are mine. When it is remembered that Nicklas's formula was evolved to apply to the sluggish and slow-breathing carp, and that the main subject of this paner is the active and rapid-breathing tront, the emphasis will be apparent. The very largest proportion of the nonnitrogenons elements of food required by the trout (and it will be very much in excess of that needed by the carp) is for the purpose of respiration. It is for this reason that the otherwise excellent article of liver, when employed alone, has not proven a perfect food for tront; aud it is partly from this reason that the Neosho method of mixing a large proportion of nonnitrogenous substance with the liver has secured such satisfactory results.

If the careless reader is inclined to ask, Why is not a food well adapted to one kind of fish (carp) equally well suited to mother (tront)? I would remind him that whereas man in the tropics needs but the scantiest quantity of fats and oils the Eskimo rerpures 20 pounds of animal food daily. $\dagger$ It wonld be a serions error to suppose that the food suited to carp is equally suited to trout, or that the food alapted to trout living in a mean temperature of $55^{\circ}$ to $65^{\circ}$ would be the best for the same fish in a mean temperature $30^{\circ}$ lower. The very change in the rate of respira. tion consequent on the change of temperature would, if the feeding was to be done on the most economical and rational basis, entail a change in the character of the food. A consideration of these facts led me some years ago to adopt a mode of feeding trout which has since become known as the "Neosho method." The following description of the method of preparing the food and feeding the fish at the Yeosho station may be of interest.

Dio Toichwirthehnft. From the Lehrbuch der Teichwirthschaft, by Carl Nicklas. United States Fish Commission lieport, 1884, p. 467. 'Translaterl from the German by Hermau Jacouson.

t Socond Vosage for the Discovery of the Nurthwest Passage (Sir John Ross). 
FISII FOOD AS PREPALEI) ANI) USED AT THE NFOSHO STATION.

The base of the food is composed of a mush made of "shorts," or mill middlings. To this mush, aceording to the kind of fish to be fed, beef liver is added in varying proportions. The mush, mmixed with liver, is fed to some kinds of tish; mixed with liver to others, and for some kimls is not employed. For making the mush we use the best quality of shorts. The poor quality will not answer, because, like corn meal, the mush made from it is too rearlily soluble in the water, dividing into finer particles than the fish will eat. To obviate this we have the miller mix from 5 to 10 per cent of poor flour with the shorts when it "runs poor." For making the mush a large, 25-gallon farm boiler is filled nearly full of clean water, which is brought to the boiling point. Shorts is then added, about 1 gallon at a time, and thoroughy stirred in. Care is taken that the shorts does not become lumpy, but has a chance to cook in an even pasty mass, otherwise portions would be raw. After enough shorts has been added to bring the mass fo a thick mush it is poured off into convenient-sized pails and allowed to cool. It has been found advantageous to allow the mush to set and harden thoronghly in the pails before using. To aid this process in the summer the pails are placed in the cold ruming water in the hatching tronghs. When thoronghly set, well harlened, it is not so likely to too freely dissolve in the ponds.

To each kettleful, of 25 gallons capacity, 30 pounds of shorts are used, producing 166 pounds of mush. To each kettle of mush, as it is being made, three to four pints of common salt is added. Whilst the shorts is being adder to the bolling water the mixture requires constant, vigorous stirring. For this purpose we use a wooden paddle with a handle 4 feet long. Forty-five minutes is usually sufficient time in which to prepare such a quantity of mush.

Four to five minutes will prepare a 10-pound beef liver for our work (except when feediug young fry), by using a No. 22 meat entter made by the Linterprise Manufac. turiug Company, of Third and Dauphin streets, Philadelphia, Pa. These machines are provided with perforated plates for regulating the size of the cut of meat. The perforatious vary from one-sixteenth to three-eighths of an inch, being ample range from smallest to largest fish, except for very young fry. When trout commence to feed the liver is run through the one-sixteenth inch plate, and afterwards is forced through a tine-wire screen. The screening of the liver is kept up until the trout are large enough to swallow the particles of meat as they come from the machine. This period varies with the development of the fish, the safe period averaging about the third month of feeding.

The very young trout have never been subjected to the mush diet, though it is not doubted that they could be induced to eat it, but they are started and kept upon a pure beef-liver diet until they are thoroughly trained to congregate for their food. When the fry have been on beef liver for abont two months we commence to mix in a little mush, and gradually increase the proportion of mush (and quantity of food) until by the time they are six months old the mush and liver may be in equal proportions. After that time the addition is made freely, so that when the fish are yearlings the liver may be reduced to a minimum. Exigencies lave arisen making it desirable to economize on liver. At such times we have not hesitated to put the tront on a diet of pure mush. They rise to the surface for this food, sometimes meet it in the air, and rarely or ever allow a particle to reach the bottom. That the fish produced by this diet are normal and healthy is beyoud all question, and it evidence is wanted it is to 
be found in the fact that their progenitors, spawning them at 2 years old, were raised on the same diet. As yearlings these fish averagen 6 inches long and 51.56 pounds to the 1,000 is sh.

The adaptability of the stomach of the tront for varions foods ras tested by the following experiment which I conducted at Neosho in 189\%. On Angust 9, 189:, 12,000 healthy trout fry, which had up to that time received the same general treat ment and allowance of food as we usually give, were deprived of all animal or thesh food. From that time until they were shipped, in February, 1893, not an ounce of animal food was given them, and it is certain that the natural animal food which they might have obtained was the very least. At the end of the year they averaged 4 inches in length, and an average 1,000 weighed 27.5 pounds. The fish were normal and healthy, and though under the average for Neosho, they were above the average of at least two American establishments.

The results to be obtained by this method are intimated above and a comparison of results may be made by referring to the table on page 295.

As to the cost of this method the following table shows the allowance per 1,000 fish from May 1 (about the average time when fry are liberated as such) to December 31. I might state that at the Neosho Station liver costs 5 cents per pound and mush one-fourth of a cent per pound. These prices will, of course, vary with the locality.

Daily allowance of food, in pounds, per 1,000 rainbou trout (Neosho method and practice).

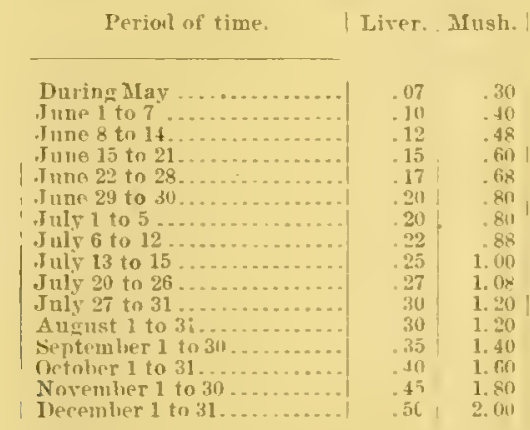

Calculations firom the above table show that the food for 1,000 rainbor trout from May 1 to December 31 (discarding fractious in the totals) amounts to Th pounds of liver aud 300 pounds of mush, costing in the aggregate 84.50 . The production for this expenditure averages 50 pounds of trout. The value of this product varies with the market, and is impossible of calculation for any specified period.

In a short article in the United States Fish Commission Bulletin for 1894, pp. 71 and 72, may be found some additional notes on the feeding and rate of growth of tront in their second year at Neosho. By reference to this article it will be seen that 1,500 13-montlss-old rainbow tront made the remarkable gain of 241 per cent of their weight in ninety days at an expenditure of 5 cents for food for each pound of tront gained. At the end of sixteen months these fish were at the best marketable weight, about one-third of one pound, secured at a cost, for food, of about $7 \frac{1}{2}$ cents per pound of fish. This very rapid development of the trout during the latter three months is not peculiar to Neosho. Señor Cházari states that the rainbor trout in Mexico attain at treight of 160 poumds per 1,000 Jearlings(!). and that "their development in the latter part of the year is very rapid." 
The trout reared at the three hatcheries where the Neosho methor of feeding is followed, namely, Neosho, Mo., Wytheville, Va., and Mammoth sipring, Ark., are not surpassed by any in the United States or in Europe. Only at the Mexican hatcheries, where the cheap labor and peculiar conditions enable them to collect and supply the natural food in sufficient quantities, are larger trout grown in the same period of time. In 1893 the method was adopted by Mr. F. N. Clark, superintendent of the Michigan stations of the U.S; Fish Commission.

Stubborn as are the facts which have been presented, the mixed riet for trout has been covertly attacked on the ground that trout, from the nature of their teeth, are carnivorous, and that it is contrary to nature to supply the domesticated trout with other than a parely Hesh diet. If onr knowledge of dentition ever reaches any degree of exactuess it will show exceptions to the general law which will refute such idle talk. It is a fact well known to all careful observers that-

All our common fresh-water tishes eat vegetable matter. All of them seem to be fond of mulberries and elderberries. Chubs, perch, eels, cats, carp (suckers) eat all grains and the meal thereof, whether whole or ground. I believe that all of the rodentia are at times llesh-eaters. Herbirora often eat flesh. Horses, mules, and cattle eat dry tish-scrap freely, In the case of fishes which scarcely chew, the dentition does not imperle a change from one sort of diet to another. The lines whichseparate between flosh-eaters and regetable-feeders are scarcely so hard and fast as are grenerally thought. - (Dr. I. G. Ellzey, ex-commissioner of tisheries of Virginia.)

The dentition argument against the mixed diet for clomestionted trout is as reasonable as that of the so-called school of vegetarians, who declare that becmse our teeth resemble those of the vegetable-feeding apes more than any other aumals our most appropriate food is the fruits of the earth. I have before stated that the trout we feed in our ponds are domesticated animals; that the jackal and the wolf are carnivorous, but the domesticated dog sickens and dies when restricted to the only food acceptable to his ancieut progenitors. It is strange and unaceountable that the average fish-culturist will persist in basing all his arguments for the determination of the food for fishes under domestication upon the linown habits and preferences of the fish in a wild or natural state. All data relating to the habits aud food of fishes in nature are of the highest valne to the fish-culturist in determining the best conditions for stocking streams, but they have no direct bearing upon what shonld constitute their food under domestication.

Dr. James A. Henshall presented at the trentieth meeting of the Ameriean Fisheries Society (Washington, D. 1 ., IIay, 1891) a paper on The Teeth of Fishes as a Guide to their Food Habits. In the closing portion of this paper he says:

Thus, by olsserving tho character and position of the tecth of fishes we have a sure and certain indication of the character of their food, that is, of their principal and natural food. Of course, there will be exceptions, hut they only prove tho rule. Au Lerbivorous fish will occasionally swallow animal foon, while a carnivorous fish will sometirues swallow vegetahle matter. " * " They should be judged, howerer, by what they feel on mostly aud habitually when situated so that they can exercise their choice in the matter, for clange of environment may involre a change of diet.

The last sentence of this quotation strikes the keynote of a mixed diet for trout under domestication. Dr. Henshall would have come nearer to the facts had he said that a change of environment (and it is a wide change from nature to domestication) frequently demands a chauge of diet.

In Forest and Strenm for November 18, 1893, over the siguature of $\mathrm{Mr}$. $\mathrm{A}$. $\mathrm{X}$. Cheney, is the following statement: 
One of our best-known fish-culturists tolil me of his experience in rearing trout for market on mammal food. Ho said he hauled lis liver, etc., to the pond in a iwo-horse wagon, and carried the trout to marketin a basket on his arm.

It is very possible that this misquided brother was one of the best-knomn fisl. culturists, but it is certain that be was not one of the knowing, for, while he was employing two-horse wagon loats of liver to produce basketfuls of trout, other fishculturists were rearing them on a mixed diet of liver and mush for 8 cents and 10 cents a pound.

On page 49 of Seth Green's Trout Culture is the statement that "trout are carnivorous, and will not eat vegetables of any kind that we have ever tried." This statement, in exactly the sime language, is repeated nine years afterwards on page 80 of Fish Jatching and Fish Gatching, published in 1879 by $\mathrm{Mr}$. Green and Mr. Roosevelt, commissioner of fisheries of New York. Mr. Green's efforts in this direction could not have been very extended. The trout at Neosho are very fond of crackers (stale oyster erackers), and I have frequently given the fry a treat of boiled potatoes, forced through a masher $(\mathrm{C}$. F. Henis patent, which I regard as superior to Sir James Maitland's feeling spoon), boiled rice, pease, and beans.

'There is a statement in Mr. Green's first book (1S70) touching the matter of feeding which takes almost the form of prophecy. On page 47 he says:

Trout can be bred to any color by fecting and the use of proper ponds, and we believe that in the future they will ho bred to color, shape, flavor, ete., with as much nicety and certaiuty as the cattle faucier loreeds his animals.

At the Vivero hatchery, Mexico, the food consists largely of Gammarus, which are there to be had only in a miry marsh. These impreguate the trout with a peculiar muddy or marshy taste. To obviate this.trouble the shrimp food is suspended some two months before the marketing of the fish, and nutmeg and ginger is added to the ather articles of food for the purpose of imparting an aroma or Havor to the flesh of the tront. If the Americau palate objects to the combined thavor of nutmeg and trout there is reason to believe that the objectionable article might be replaced by some other Havor more acceptable. It is the writer's opinion that such a condition as prophesied by IIr. Green can not be induced by the use of a mammal diet solely; but Señor Cházari has demonstrated the possibility of flavoriug the trout flesh by mixing vegetable with animal matter.

Shonld it be urged that trout raised ou a mixed diet and intended for stocking streams would, when liberated, by reason of a perverted nature and taste, be untitted for natural food, I may answer by referring to the dilliculty of retaining fow ls which lave been hatehed from eggs taken from wild nests. In infancy they liwe, thrive, and fatten on the farm grains and kitchen seraps of bread and meat. One fine day they leave for the woods or moors. Is it reasonable to suppose that they die for want of the diet which served them so well in,intancy? The process of reversion from domestication to nature is always easier than the change from nature to domestication.

Little as is known of the colrect rations and best food for fishes muler domestication, there is less known (and from the uature of things it will be more dificult to determine) of the very inportant and high-power factors of range and space in determining the development and rate of growth of fishes. It is well known to every culturist of experience that these are factors which should not be disregarded, and if disregarded neither extra feeding nor additional water supply will compensate for the lacking elements. At first, range and space may seem to iuvolve natural food, 
and it must be admitted that to some extent this is so. But it is known that in pools where the natural food is necessarily of a minimum quantity for if the pool is at all well stocked it can only be that introduced in almost microscopic particles by the intlowing water) a given number of tront would be outstripped in wrowth by half the number on the same rations per thousand fish. This has been ascribed to exercise, freedom of movement, a larger quantity of oxygeu per fish, and various other causes.

Other things being equal, it is certain that the temperature of the water and the proportion of the pond or pool subject to renewal each minute, or hour, will be found controlling factors of no small consequence. Of course, these elements may be, and sometimes are, disregarded to the point of aspliyxiation, but they are here mentioned only as they influence development and growth. It seems certain that trout raised in a high temperature grow more rapidly than those living in colder waters, and it is more than probable that where the current is very swift too much aliment is demanded in the work of living. It is true that in the natural home of the trout many fine tish are caught in the swiftest waters. Because primarily they are fine fish they are able to stand the exertion and strain of living in this swift water; and so, being in position to catch and enjoy the abundance of natural food which the current washes down from the sources of the stream, they become the finer. A gain I would warn the reader not to confound domesticated trout in pools wibl wild trout in mountain streams. Mr. Livingston Stone lays stress ou cold, sunless water and close confinement as dwarting influences on trout, and urges the desirability of an abundance of warm water, range, and plenty of space in growing large trout.

'The following notes on the feeding of other species of fish at Neosho may be of interest:

Black Bass. - The black bass (Mieropterus sulmoides) decline a vegetable diet in any form, and can not be male to eat it. When mush is sometimes mixed with a considerable quantity of liver they will take it in the mouth, but quickly spit it ont. The same results have attended frequent trials with crackers, bakers' bread, and dog* biscuit. 'They seem averse to vegetable diet, no matter how well disguised with a mixture of meat. I have been unable to induce them to take artificial food except liver, aud it must be fresh and sweet. Of course, minnows or other tish have not been tried, the effort being to overcome their natural inclination to eat fish. When the liver, as it will occasionally in summer, becomes the least bit tainted the bass refuse it. Sometimes they decline everything. This peculiarity of the bass is well known to anglers. * In the Neosho ponds the bass rarely eat on nasty, raw days, but on pretty, clear days they follow one around the pond, seeming to beg for food. 'The food of the young bass was discussed in my paper, The P'ropagation of the Black Bass in Ponds. $\nmid$

The Rock Bass (Ambloplites rupestris).-In the first efforts at Neosho to feed these fish a small quantity of liver was daily put in their pond, but it is doubtful if they ever swallowed any of it. Sometimes they would pugnaciously dart out and take a small piece in the month, to immediately spit it out. Formerly every few days a small quantity of liver was put in their pond to assist in breeding the insect life which furnishes the largest and wost acceptable part of their food. For two years past no artificial food has been expended on the rock bass. 'I'heir pond, of only 9,000 square feet water surface, is well planted with Potumogeton and Eloden, on which the smaller crustacea breed in such quantities as to support from 10,000 to 12,000 1rock

\footnotetext{
* Book of the Black Bass, James A. Heushall, 1. 360. † U. S. 1. C. Bulletin, 1893, 11p. 229-236.
} 
bass each year without the introduction of any other food. Apart from any consid. eration of the value of these fish, they are the cheapest boarders at the hatchery.

The Channel Cutfish eat the mush greedily. During the fall; winter, and early spring they were dormant, and did not come for their food. Such as was offered them during this period sank to the bottom and remained unnoticed. At other times of the year they rose to the surfice and ate the mush ravenously, reminding one of pigs. They are, as is well known among anglers, very fond of liver, it being a favorite bait for them among the negro fishermen of the South. Very rarely we mixed a small amount of liver with their mush*.

The Carp and its Allies. - The food for these fishes has received such excellent treat ment at the hands of Mr. Carl Nicklas that the reader is referred to the translation of his Pond Culture, to be found in the Report of the U.S. Commissioner of Fish and Fisheries for 188t. But I would state that in ponds not overstocked I loave never found it necessary to employ any animal diet for this class of fishes, though it is not to be doubted that the lines of feeling laid down by Mr. Nicklas will produce the most satisfactory results in securing the best marketable weight in the shortest time.

NATURAL FOOD.

The artificial propagation of natural food for fishes reared artificially las received the serious consideration of European fish-culturists, and several of them claim to have reached the solution of the problem and to be now rearing uatural food in any desired quantities at a not extravagant cost. Foremost among these was M. Lugrin, of France, a description of whose secret process may be found in the frequently quoted artiele published in the Bulletin of the U. S. Fish Commission for 1887. The hope was held out last year, in the neeting of the American Fisheries Society, that the French Goverument contemplated purchasing the secret of M. Lugrin and throwing it open to the public use.

Mr. Thomas Andrews, of England, also has for some time past been engaged in rearing matural food, but, from my understanding of his letters, his process seems to consist in allowing the natural food, principally Gommarus and Limmen, to multiply naturally in reserve ponds and transfer the surplus to the ponds containing fish.

The method of Mr. C. G. Atkins, of the U. S. Fish Commission, ean searcely be called, in the strict sense of the term, antificial propagation of natural foorl. $\dagger$ I take it that maggots are in no sense natural food for Salmonidre, and I think that the method, because of its extreme malodorousness, will never be acceptable to the attendant or the community in which the work is conducted.

Señor Cházari, of Mexico, uses natural food in considerable quantities, which, by renson of peculiar environments and cheap labor, he is able to collect at the low cost of '2.1 and 3 cents per pound. I understand that he neither breeds the insects after the style of M. Lugrin nor uses reserve pouds after that of Mr. Audrews, but relies on neighboring swamps as a base of supply. The local technical name of the Mexican food is "mosquitte," and in answer to my iuquiries Señor Cháari wrote as follows:

It is a kind of alquatic insect, boing prodncel in large quautities in our lakes pertaining to this listrict, especially in that of letcoco, and from which considerable quantities are collected every year, mixed with larva and otluer aquatic iusects. It is utilizorl extensively as a food for singing birds. It is a species of torise, thu Corizafemorata. It is very rich in "azoil " priuciples (as arealmost all insects), and even more than others, and therefore is considered an excellent food for fish. I have preferred it.

U. S. Fish Commission I3ulletin, 1883, 1. 419; 1881, p. 321; and 1886, p. 137.

+ Bulletiu of the U. S. Fish Commission, 1893, pp. 221 et seq. 
in view of these highly estimable qualities, and because it can be given to trout without any mechanical preparation, even to the smallest. Some 20,000 or 30,000 pounds a year are collected. * * * Its only defect is that it keeps but for a short time. It rots, and is clevoured rapidly by other insects developed in it.

In the same letter it is stated that rainbow tront at 1 year old, fed on Corizu, attain a weight of 160 pounds per 1,000 fish. I know of no other place where attention is given to the Coriza except the Neosho Station, where it is not used for the trout but for the pond fishes, black bass, rock bass, ete.

Last year Mr. A. N. Cheney called attention to the methods of the Austrian, Carl Elder von Scheillin, who says: "'I, by following further on the lines of the Frenchman, Lugrin, have solved" the question of proper food, "and have tested the solution as good, cheap, and practically feasible." Mr. von Scheidlin has proposed, through Mr. Cheney, to make over his method of rearing natural food for use in the United States, and correspondence is now going on to that end.

Up to the present time the ouly tangible efiort of a European in the direction of cultivatiug natural food for fishes which the American fish-cuiturist can take hold of has not been accomplished by a fish-culturist, but is the result of investigations and experiments conducted by Dr. W. Kochs, of the University of Bonu, on the Artificial Propagation of Minute Crustaceans. The results of this work appeared in Biologisches Centralblatt, October, 1892, and on aceonnt of its exceeding value a full trans. lation is oftered on Pp. 306-30s of this paper. Ocension is taken to recommend for consideration, particularly of the pond culturist, the suggestion of Dr. Kochs to construct insect-breeding ditches along the banks of the ponds, from which the infusoria and crustacea may find their way into the ponds. Observation has fully conviuced me of the value of the hint given by I r. Kochs of the fondness exhibited by Gammarus for dry brushrood, and I might state that the same seems true of all woods in which decay has commenced; Coriza iu particular seems to frequent half-rotted logs lyiug in warm, sha!low water, though I believe Gammarus prefers clean running streams. I have found it most abundant in water of a temperature not unpleasant tor drinking.

Translations of portions of reports by M. Chabot-Karlen on the tish-cultural operations of MM. Durand, Binder, Després, and other culturists of France are sub. mitted on 1 \%. 309-311. I would invite attention particularly to M. Durand's method of propagating the Cyclops, and I an prepared, from my own observatious, to unquali. fiedly indorse his remarks as to the value of Potamogeton and Nusturtium as a shelter for the smaller crustacea.

As before intimated, little or no systematic attention, except on an experimental scale, has been given this subject by American fish-culturists; the only approach to the European method of which I am aware being that at the private ponds of Mr. Fairbank, of Illinois, and even there the effort is like that of Mr. Andrews.

One of the objections which has beeu raised to the employment of natural food is the time and expense which would be involved in collecting enough for feeding a large number of fish. To this I make answer: First, be certain how much food you need to produce the best results. A comparison of the values of difterent foods as determined by chemical analysis and as exhibited on page 295 will show that from 7 to 10 pounds of the artificial food may well be replaced by 1 pound of natural food. I say well replaced, because if 1 pound will do the work why burden the system with the useless 9 pounds ?

* U. S. Fish Commission Bulletin, 1893, p. 278. F. C. B. 1894-20 


\title{
EXPERIMENTS WITH ARTIFICIAL, PROPAGATION OF MINUTE CRUSTACEANS**
}

\author{
By DR. W. Kochs, Univirsity of Bonn.
}

Within the last twenty years fish-chlturists have become more and more convinced that the knowledge and dissemination of minute crustaceans and other lower animals inhabiting fresh water are of the greatest benefit to fishing. The growth of the young brood and the faculty of the fullgrown fish to increase under favorable conditions are in the first instance regulated by the facility of obtaining good food, and this regularly and abnudantly. Emil Weeger delirered an interesting lecture on this suluject at the International Agricultural and Forestry Congress at Vienna in 1890, which was later published with illustrations showing "strongly magnified representations of several species of crustaceans frequently found in the waters of central Europe and insects belonging to the family of grats, May tlies, and daytlies, all serving as food for fishes."

At the close of this lecture Victor Burda, fish-culturist of Bielitz, spoke on the same subject aud adiled, relative to the propagation of fish in large ponds, that these small infusoria were not only of the greatest importance for salmon-breeding, as stated by Weeger, but also for carp-breeding; it was a subject which would lemand the greatest attention amoug experts, because it was known ever since the well-known expert, Director Lusta, had lifted the veil behind which the question of the nutrition of the carp had been screened for so loug a time, that the principal food of the carps, like that of the salmon, not only in its earliest stage, but also later, consists of animal life, and he asks why the artificial breecling methods of the water fauna, as suggested by Weeger, should not be adopted.

Mr. Burda then continues and points ont some measures by which the propagator might exert a beneficial influence upon the growth of this minute water fauna. Starting from the idea, and this illea is correct, that the minute crustaceans live on infusoria, and that these intusoria again thrive on plants in the process of decomposition and on animal life, he endeavors to supply the ponds with the necessary and appropriate food. He says:

"The decomposed substance serving as food for the infusoria accumulates on the bottum of the pond, aud is also mechinically distributed in the water, giving it a muddy alpearance. 'The substance distributed in the water partly originates on the bottom, partly enters the pond with the new influx, in which case it comes from the soil, near by or far off, accorling to the condition of land or water, The more lusuriant and the more fertile the laud the richer the ingredients washed into the pond. It is, therefore, of the greatest importance to have the greatest amount of this uuddy intlux led into the poad after a heavy rainfall."

This 18 donbtless correct, but it is also a fact that this acquisition to the pond is gained at the expense of the surrounding lands, because they are impoverisherl by the heary rainfalls. Of courso considerable values in the shape of organic and inorganic snbstances wash from the fields in to the brook, from there How iuto the rivers, and then into the ocoan, and so wonld become lost if they were not collecter in the ponds and subsequently absorbed bs the fishes. But a correct pourl propagation must not depend on circumstances; just as a certain quantity and quality of manuro must each year be supplied to the field to prodnce fair crops, 80 the same action must be taken in regard to the fish ponds. Dr. Kochs tried for a year to catch the crustaceans described on IVeoger's plates and to breet them in glass vessels holding from 8 to 10 liters ( 1 liter is equal to 2.113 pints) for the purpose of investigating their conditions of life. He fonnd them only in puddles, which received their fertilizing substance from the surrounding land or from animal cadavers. In ono case, in a puddle in a clay pit near Winterschlick, he found that dung particles had been washed into the puddle from an adjoining sloping orchard, where numerous dung heaps were found. The consequence was a luxurious vegetation and numerous crustaceans in this puddle, while in many other adjacent puddles harlly anything living could be detected.

It is not essential to catch a great number, because they increase wonderfully. To obtain those species in a perfect condition, which collect between the water plants, he used a pear-shaped pipette bolding 1 liter, having a long and strong, but narrow, neck, and on the other eud, in the pear, an aperture 1 contimeter wide. When, closing the uarrow neck and placing the pear end of the vessel in the water, the stopper is suddenly removed, the water will rush into the vessel, carrying with it the small infusoria. It is not possible to catch nearly as many with mull netting, besides the latter is unserviceable between the water plants, and it is difficult to separate the infusoria from it.

Dr. Kochs has prepared since $J$ une, 1891 , a number of glass vessels as aquaria, in each of which ho placed all kinds of crustaceans. Some he kept at his private residence in the open air and during the

\footnotetext{
"Translated by H. H. Gerdes from IBiologisches Centralblatt, Band XII, pp. 599-606.
} 
winter in a warm room; others le kept in the Pharmacological Institute in a room not heated, but not exposel to frost; others, again, since January, at the Physiological Laboratory for Animals at the Acaleny of Toppelsiorf, near Boun, in a room exposed to all atmospheric changes. One set of the arnaria was prepared as called for by Weeger; that is, 10 cubic centimeters of garden soil were placel on the bottom and soaked with liquid mannre; on this was placed mul from the puddles containing crustaceans, and on this, again, dry leaves of hazelnut and willow trees. The aquarinm was then filled up with witter. Some fliform algie, Wolffa, and other small water plants had entered into the aquarinm with the mud. In the course of two weeks there developed in all the aryaria minute crustaceans (shell insects, lea lobsters, water multipedes, infusoria, green algre), a felted mass of filiform alge, and a thick cover of Jolffia. The warmer the aquarium the quicker and hetter was the development, but the plant life seemed to prosper better than the animal life. By catching these small crustaceans in proper pipettes it was shown that the quantity in the aquarium was less than in runniug water.

Subseruent experiments proved that the majority of the crustacea were very easily affected by even the smallest (1uantity of ammonia, sulphureted hydrogen, or free scids, as also stated by Weeger. It is clear that only the most furorable conditions for the development of the crustacea in the aquaria prepared accorling to Weeger are mentioned. Then comes a perioul, which passes quickly, developing a good cleal of this animal life. Dr. Koche tried to accelerate the increase by throwing in small pieces of meat or dung, sometimes with more or less success, and to raise larger individuals, having the most success with the water multipedes.

These experimeuts soon convincel him that water in which the crustacea grow well and increase was too nnclean for most fishes; moreover, the crustacea reruire warm and moro or less stagnant water, and can, therefore; only be raised in slallow puddles exposed to the sun and containing many water plants, whereby it is clearly shown that the propagation of infusoria for fish food must be entirely separated from the breeding of fishes. When attempting to breed both in the same ressel, either the water fauna prosper and in that case the fishes can not live, or vice versa. Ho ascertained, also, through special experiments, that the minute crustacoa could hardly live in water most favorable for the growth of microscopic plant life.

Mixing 0.1 liter of uitrate of aumonia, 0.1 liter of biphosphate of potash, and a minute quantity of irou with the strongly calciferons water from the city hydrant in Bonn, and alling a small number of water plants, the water will snou turu strongly green and turbid at a temperature of from $10^{\circ}$ to $12 \circ \mathrm{C}$. ( $50^{\circ}$ to $51^{\circ} \mathrm{F}$.), aud becomes slimy on account of the algre. Daphnia and Cypris will harilly grow therein.

His aim to first produce, in the proper manner, large quantities of greenish water rich in plant life for the sustenauce of the crustacea proved a failure. Still it is true that many crustacea live on microscopic plants, but the most favorable conlition of life does not tally with that of the plants.

The crustacea aro ouly good in transparent aul clear water; all the fine aquaria tested for years contained large water plants, but also alwass clear water.

Later lie experimented as follows:

To make the method to breed crustacea artificially practicable and feasible the material needed must be easily accessible and cheap. If the breeding is done in special receptacles (reservoirs) it innst bo done in snch a way that it will be easy to get the infusoria clean when fed to the tishes. 'The following experiment led him to a procedure which in his opiuion will prove successfui: Taking two glass ressels each containing 10 liters of water (21.13 pints) and adding $100 \mathrm{grams}$ (3.53 ounces a voirdupois) of fresh cow manure without straw in such a way that in one ressel this manure is evenly distributed, while in the other these 100 grams of manure are placed in a glass cup and covered by wire netting, it will som be observed, especially where the temperature is warm, that a strong decomposition takes place in the first-mentioned ressel, a thick scum of bacteria is formed, the liquid turns light-brown and smells strongly of musk and ammonia. Cypris and Daphrie may live, and oven increase, in this bad-smelling liquid, if the temperature is not too high, and under the described conditions. On the wther hand, there is hardly any smell in the second ressel, where the manure is inclosed in the cup. The gases forming in the manure raise the cup, bottom upward, to the surface of the water, which is soon covered with a scum consisting of numerous bacteria and infusoria. The outer side of the wall of this cup, and also the bottom of the large vessel, is soon covered with a whiteslime, also consisting of bacteria and infusoria. After some time only organisms are developed containing chlorophyl (green coloring matter of leaves or plants) in large quantities. Daphnia, Cypris, Cyclops, and many other crnstacea grow tinely in such a vessel. The wire netting which prevents the cow manure from mixing with the water is thickly corered with minute crustacea searching for food. As the water 
remains nearly clear, it is somewhat ensy to catch the animals, and one may so becone convinced of the phenomenal increase.

Under the influence of water and warmth a vast development takes place of those numerous mieroorganisms contained in the cow manure which absorb the undigested parts of the nanure, aud which serve themselres as food for the crustacea. The manure gradually disappeared during the montbs of May, June, and July. When theso crustacea are fed to small carp or goldfishes a gradual trausformation of cow dung into fish is accomplished, almost withont the help of plants.

The Gammarus pulex has lately frequently been found in large quantities between old bricks and half-rotten brush wood in the Endenich Brook, near Bonn, without any cells containing chlorophyl having been found in the water or mud. The water of the brook was mudly, because it containerl the wasto and drainage of several adjoining villages. This relatively large crustacean grows splendidly in an aquarium prepared with cow dung, as previonsly described, if a little dry brush wood is added.

Practically, it will be easy to produce this transformation of cow dung into fish, subject to local conditions. The most adrantageous way would seem to be to dig ditches along the banks of the pond about 1 meter wide and 25 centimeters deep (about 40 inches by 10 inches) connected with the pond by numerous narrow cuts. Perforated boxes or flower pots filled with cow dung aro then placed in these ditches and protected from the rays of the sun. When this shallow water is warmed by the sun a great quantity of infusoria and crustacea will develop, which by the rise and fall of the water in the pond are sucked into it. If the banks of the pond are low, the fertilizing substance will settle there, thus enlarging the area for the breeding of the crustacen and forming a feeding-plaoe for the joung fishes.

All these infusoria are especially sensitive to light. The ditches and banks must have old bricks, brushwood, leaves, etc., for the protection of animal life. A luxuriant growth of water plants, especially ITolffia, must be prevented, because it absorbs too much nourishment frow the water; that is, the nourishment is collected in the plant in such a shape that it is unserviceable for the purposes of fish propatgation.

These breeding ditches must, if possible, be dry in winter, so that the frost may easily penetrate. In that case the winter eggs of the crustacea, bedded in the mire, will develop better and more numerously in the spring than when having overwintered in water. It would be very interesting, but very difficult, to determine the causes of this pecnliar process. Dr. Kochs exposed the mud of several arpuaria in an open box to the sun, to rain, and to frost by keeping it in the gutter of the roof of his residence. By putting samples in glass vessels filled with boiled hydraut water and placing them in a warm room, there developed within three weeks $C y p r i s, D a p h n i a$, and microscopic wheel animalculie, especially Hydatina senta and infusoria. It is certain that the eggs lad several times been exposed to $-10^{\circ} \mathrm{C}$. $\left(14^{\circ} \mathrm{F}\right.$.). At the end of May several samples of the same, now air-dried mud, were put into water previously boiled, and in two weeks numerous crustacea hat again developed. By drying a large quantity of egg-containing mud in the fall, the proper food may easily be bred in the spring and summer.

It must here be stated that the eggs will not stand a drying over sulphuric or anhydric phosphoric acid. When that is done they all die, as has often been observed. This is mentioned becanse it is frequently asserted that the eggs of the lower animals may live for one or more years in the thoroughly dried mud puddles. Even mud, eleft and disrupted by the action of the sun, still contains several parts of water. A total drying up of the egrs, therefore, does not take place in uature.

Dr. Kochs made special experiments with the Helix pomatiu, aud found that under the usual conditions the moisture of tho living animal does not dry up in a year, even in a warm room; moreover, as soon as a dry crust has beeu formed around it, it loses the moisture only in artificially dried air, but it dies before all the noisture is alssorbed. The poisonous substances formiug at the bottom of the ponds by a slow decomposition of organic substances at such times of the year when there is no frost are destroyed by the plant life. These infinsoria, and also the egrs of the lower animals, are frequently threatened by an accumulation of those poisonous substances during such times in winter when this process does not take place. Half-dccomposed organic substances are loosened and made spongy by the frost, and later on easily erumble or dissolve. Only the drying and freezing of the mud, therefore, can be recommended.

* I think it pertinent at this point to remark that Dr. Kochs's warning against allowing a luxuriant growth of water plants in the ponds has reference to his method of "trausforming cow ilung into tish" without the help of plants." Ordinarily - that is to say, naturally - the vis or fortilizing strength of the manure would go to making a lnxuriant growth of plant life, which in turu would be couverted into the low forms of animal lifo exhibited in tho infusoria and crustacea. 


\section{REPORT BY M. CHABOT-KARLEN ON THE FISH-CULTURAL OPERATIONS OF M. DURAND, AT THE SCHOOL OF AGRICULTURE AT BEAUNE.*}

The anthor states that fish-cultural operations were commenced at the School of Agriculture and Viticulture of Beaune in 1886-87, near the Bouzaize, one of the afluents of the Sanne; that there were at the time no tront in the vicinity or in the neighboring rivers, and that it was necessary to buy eggs. The first year 12,000 fry were obtaiued, which were divided into three lots. Two lots of 3,000 each were planted in the Onche and Muzin: the rest were liberated in the Bonzaize or lield in confinement near the shore and fol ou Cyclops and afterwards on Gammarus. The second year 17,000 fry were obtained; the two rivers aloovo named received 6,000 , the Vouge but 1,$000 ; 500$ were planted in the Love, and the rest put into the Bouzaize, a part at liberty and a part iu confinement. At the present time 18,000 fry are realy to be distributed. In three seasons 47,000 fry have been turned out.

In the Ouche, in which the trout were provionsly unknown, it is now possible to take them weighing 400 grams (aljout 14 ounces), those that were put in first being 23 months oll. M. Brossarl, director of bridges and roals at Bligny-sur-Onche, says that numbers of them of this weight can he seen in the upper parts of the stream. As to those 1 year old, they have attained a weight of $100 \mathrm{wrams}$ (abont $3 \frac{1}{2}$ ounces). Mnreover, natural reprouluction will commence next season, and tho conditious in this river are so farorable that its stocking by this methol is assured, as the fish will he in comlition to spawn in December, 1889. In tho Muzin the same results wonld have been obtained had it not been for poaching. Nevertheless, in spite of this and of the devires of every kind that were employed by the mills along the stream, the tront reappeared in the Muzin.

Inre or less similitr results were obtained in the Bonzaize. Reared in captivity in receptacles abundantly provided with aquatic plauts, l'otamogeton and cress, and fed with Cyclops and arquatic litrie of every kind at first, and then with Gammarus, the tront gainer in a year an average of 60 . srams (abont 2 ounces). At this age they were not able to cope with the larege pike that iufestenl the mill course at the heal of the river; this was euptied and the larger ones taken ont, only those of the size of the young trout being permitted to remain. Now, at the age of 23 months, a great number of the trout weigh more than 300 arams (about 10 tounces). The following are the weights of some taken in the river: First, 305 grams; second, 360 grams; third, 280 grams; average weight, 335 grams (abont $11 \frac{1}{2}$ onuces). So that in a year their weight iucrensel frotn $60 \frac{1}{3}$ to 335 graus, a gaiu of $274 \frac{1}{3}$ grams in twelve months. Natural reproduction may be expected to commence in this river from December, $18 x y$

The report also contains observations on the Cyclops (which are presented with a view to furuish. ing the basis of a method for the rearing of these), the Daphnia, and the Cypris, with some remarks on the monstrosities found with thus egrs of the trout and a statement of prices obtained for trout.

The Cyclops possesses an extriordinary fecundity, and reproduces at at temperature of from 80 $10^{\circ} \mathrm{C}$. $\left(16^{\circ}\right.$ to $50 \mathrm{~F}$ about). In winter they seek the bottom and hibernate in some sort, but on capturing them and placing them in a high ${ }^{2}$ temperature their generative ormans will be secn to revive. Thirty-five degrees $\mathrm{C}$. $(9.5 \mathrm{~F}$ ), however, accorling to our experience, is tho highest they can resist. The best for luatching is between $20^{\circ}$ aml $25^{\circ} \mathrm{C}$. (68 and $77^{\circ} \mathrm{F}$.). At this temperature there forms on ench female every two ilays two erg-bearing sacs, or external uteri, wherein tho exgs are Latcherl. At the end of two days these organs become detached aud fall to the bottom. The number of egers contained in eacil may be from 16 to 32 , but generally the number of yound obtained is somewhat less. Hovever, the eggs hatch immediately, and the sonng Cyclops which issue forth are almost globular, having but four feet and no tail. At the end of fifteen dass they undergo a molting, the tail appears and other feet form, and fifteen days after-that is, a month in all, the Cyclops are mature and ready to reproluce.

With such fecuulity, it can be rearlily understood how numerous they become. Carbonate of lime is necessary in th. formation of their shell. From the fact that they are found in abundance in water infusel with veretable matter in decomposition, the water, nerertheless, not contracting the least odor, it is supposel that they live on infusoria, and that, therefore, the means by which the fishculturist may have them at his ilisposial is to multiply in his rearing pouls aquatic plants. (l'otamo-

* The report was publisled by the National Society of Agriculture of France, June 19, 1889. The papers in this Appendix were translated by Mr. F. P. Femell, of the.U. S. Fish Commission: nono of thom have been translated in full, only such portions being presented as apply to the feeding and rate of growth of the fishes. 
geton crispus gives the hest resnlts.) In this way the Cyclops will live and reproduce with the joung fish. By digging in a neighboriug field one or more holes into which is introduced a small stream of water and placing therein the Potamogetons and fountain cress (Nasturtium officinalis?) (this lnst agrees with the Gammarus) a temperature will be obtained at which the Cyclops can propagate in great numbers; and there will be at had in abnulance the best food that can be given to the young fish. The fish-culturist who possesses clayey land can undertake this without expense. In basins so prepared it will not be long before couferve and vaucherias will be seen to form, which, after a while, becoming decomposed, will take on a brown tint, and in the midst of which the little creatures will be very abundant.

For collecting the Cyclops a simple net is used, similar to that employed by entomologists. This lets the water pass aud retains a multitude of animalcules, not ouly Cyclops, lut the larvo of gnats, Hydrachnas, etc., of which the fry are very fond.

The rearing of Daphnia mulex and Cypris fusca was also tried. The Cypris, however, were found to prey upon the young fish. Having been put in with the embryos of the carp, they were often discovered to the number of two or three fixed upon the back of an alevin devouring it, notwith. standiug the eftorts of the poor animal to shake itself free. It was, therefore, necessary to abandon their use, and with regret, becanse their fucuudity is certainly much greater than that of tho Cyclops, and they mature much more quickly. It is believed that this fact is absolntely new in the history of applied fish-culture.

Finally, attention is called to the great number of moustrosities found among eggs taken from the tront at Vougeot, at the establishmeut of M. Peloux. These breeders were reared by M. Peloux and came from the same parents, and it is asked whether these deformities may not lue attributerl to consanguinity.

\section{REPORT BY M. CHABOT-KARLEN ON THE FISH-CULTURAL OPERATIONS OF M. BINDER, PROFESSOR AT THE SCHOOL, OF AGRICULTURE OF SAINT-RÉMY (HAUTE-SAONE).*}

In this paper it is stated that during the three years that fish-cultural operations were conducted at this school 100,000 trout were planted in the Lanterne and Moselotte; and that such grood results were obtained in the Lanterne that the foung fish could be seen therein as numerons as minnows; that those 14 months old weighed 8 to 16 grams $(0.28$ ounce to 0.56 onnce) with a length of 7 to 12 centimeters ( 2.75 inches to 4.72 inches).

\section{REPORT BY M. CHABOT-KARLEN ON THE NOTES OF U. IOSPRES, PROPRIETOR OF THE FISH-CULTURAL ESTABLISHMENT OF NANTEUIL-EN-VALLÉE (CHARENTE).†}

This paper has reference to the notes of M. Després on rearing salmonicle by artificial food. He says that the clevelopment of the embryo especially attractel his attention; that it was hetween the third and fourth day lefore the absorption of the sac that the alevin would become hungry and commence to eat, not seeking its food, but lying in wait for it; that six or seven days after it would quit its hiding-place and attack its prey, snapping at it while in movement in the water. He then enters into a description of the means to be employed for the protection and feeding of the young, and he seems to have succeeder in his experiments it', as he says, lie is alsle to guarantee the rearing of 30 per cent. At Howietoun it is on the weight (one-fiftieth of the living weight) that is determined the food to be given, a method which appears more scientific and at the same time unore practical than that of feeling them without regard to age or development. The choice of fool largely depends upou environment. At Howietoun mollusks are used to a great extent, while at Nantenil hrains, blood, and Iimax satisfactorily replace these shore animals, of which the alerins are very fond.

"Published by the National Socioty of Agriculture of France, June 30, 1886.

tPresented to the National Society of Agriculture of Frauce, June 30, 1886. 


\section{REPORT BY M. CHABOT-KARLEN ON THE VIEWS OF M. EYILE RIVOIRON ON THE REARING OF TROUT BY NATURAL FOOD.*}

M. Rivoiron says that the young trout do not take food except when it is moving in the water; that they do not go to the bottom. Unless great care is taken, which is not always possible, failure is certain in the use of artificial food on account of decomposition. Of the natural food M. Rivoiron prefers the Daphnias. To rear these he says: Dig near the side of the stream two, four, or six basins, from 10 to 12 meters (abont 32 feet and 9 inches to 39 feet and 5 inches) long, lyy 2 meters (6. feet) wide, and $1 \frac{1}{2}$ meters (alout 5 feet) deep, according to the number of Daphnias to be produced. Clayey soil is preferable, as the water with which the basins are filled will not quickly evaporate. In these there should be placed during March, at the north end, hecause the basins should be dug as noar as possible from north to south, one cubic meter (about $1 \frac{1}{8}$ cubic yards) of fresh dung (cow dung and horso dung mixed).

Every day the water should he stirred until it takes on a light-brown color, withont, however, becoming tainted. On this point depends somewhat the success of the microscopic beings that during the first days of April shonld be deposited there. At a temperature of 25 C. (77 F.) each of theso will give birth every fivo lays to eight others, which in a few weeks will amonnt to millions. They reproduce even at a temperature of $32 \mathrm{C}$. (about $90^{\circ} \mathrm{F}$ ), and sustain a temperature of $-6 \mathrm{C}^{\circ}$ (about 21 F.). The least shock will kill them en masse. Under no circumstances should the water be disturbed, and they should be gathered with the ntmost eare. This gathering (a sort of skimming) can he commenced at the end of April and continned until the end of September. It can be done by means of a strainer, which should le brouglit gently to the surtace. Before lieing given to the alevins tho Daphnias should be placed in fresh water, in order to ricl them of the odor with which they may be impregnaterl; otherwise they will kill the young fish. It is supposed that the ammonia in the rearing basin is the cause. A basin should never be fished to the bottom, and eight or ten alays should elapse, acenrling as the temperature will havo more or less favored the multiplication of the crustacea, before recommencing the operation. When giving them to the alovins the same precautions should be taken with the Daphnias as when collecting them, and it is essential that they ahould bo deposited in tho water very slowly. A basin of the above dimensious will cost 35 francs, and will furnish, from April to September, from 170 to 180 kilograms (374 to 396 potuds, avoirdupois) of Daphnias. An alerin so fed will weigh at six wonths 6 grams $(0.21$ ounce), with a length of 6 centimeters (about $2 \%$ inclies).

* Male to the National Society of Arriculture of France, July 1, 1885. 


\section{BIBLIOGRAPHY.}

[The following table contains a partial list of references to articles on the food of tishes, artificial and natural, unuer domestication aul in nature. The abbreviations $\mathbf{R}$ and $\mathrm{B}$ are for the lieports and Bulletins of the United States Fish Commission, ' $\mathrm{f}$ for the Transactions of the Americau Fisherier Society, and yas reference to miscellaneous publications, a list of which is given at the close of this appendix.]

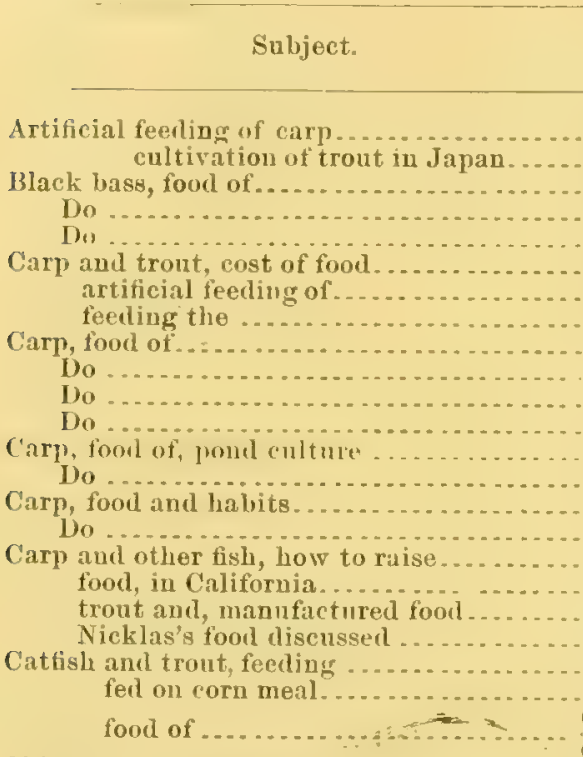

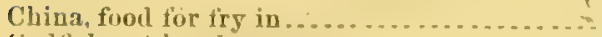

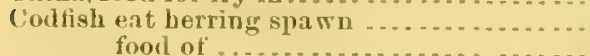

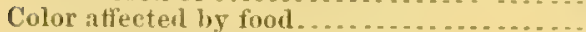

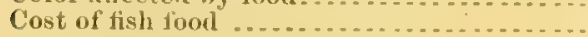
fool for carp and trout ..........

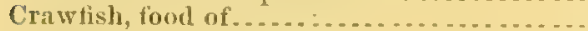

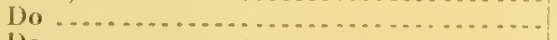

Crustaceans, cultivation of, for fish food...

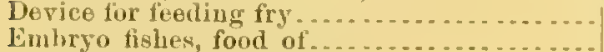

Expenses of food of fresh-water fish...............

Fish fed by lakedwellers..................

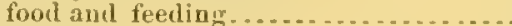

Fish, food of . . . . . . . . . . . . . . . . . . Do.

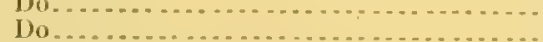

Fishes in confinement, food of$$
\text { tooul of }
$$

Food tish and fish foot.

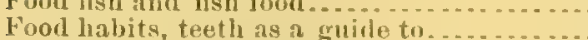

Fresh-Tater tish, axpense of

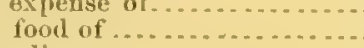

Fry, device for feeding.

Gidus morrhua

German fish, food and digestion.............

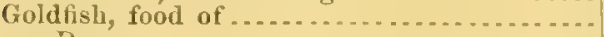
Do.

Gourami, foul of

Grayling, food of

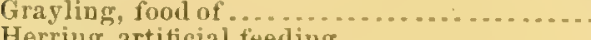

Herriug, artiticial feediug ..................

Author.

Carl Nicklas. Sekizawa Akekio...... Dr. J. A. Henslaall .... Discussion ............

A. J. Malmgren ....... Carl Nicklas.

I)r. R. Hessel.

L. B. Logran . .

I)r. R. I Tessel

Carl Nicklas

C. IV. Similey

Arolph fravel

Carl Nicklas

Hugh D. McGoveru...

.do - .....................

Max von dem Borue...

Robert A. Poppe.....

Dr. C. O. Harz ........

Baron von $K$

d. I'. Gardner

Naman MIny.

R. O. Siceuey - - - -

B. F. Jones ...............

H. Kopsch.

Prof. G. O. Sars .................

II. Friele

TII Bean

Dr. Goldsmith

A. J. Malmgren

German Fishery Asso"u

N. Wergeland

II. Rubelius.

N. Wergelaud.

IV. O. Clambers.

J. A Ryler

J. J. Mauley

Cirl Peyrer.

J. P. J. Koltz.

Philo Dunning

Eugeno lilackford ....

V. Hensen.

Ereal Yather

A. $\mathrm{X}$. Cheney.

....do.

Dr. J. A. Heusliall

J. J. Manley

Silnes I. Suith.......

W. O. Chamhers

Karl Dambeck.

Dr. P. Pancritius.

Deutsch. 1'. Keit.

Hugo Mulertt.

Theodore Gill ............

Prof.J. IV. Milner....

H. Widegren ..........

\begin{tabular}{|c|c|c|}
\hline $\begin{array}{l}\text { Publi- } \\
\text { cation. }\end{array}$ & Vol. & Page. \\
\hline $\mathbf{R}$ & 1882 & $1009-1031$ \\
\hline $\mathrm{K}$ & 1879 & 646 \\
\hline$\$ 1$ & $\ldots$ & $161 \mathrm{et}$ ser \\
\hline$\Gamma$ & XX & 8 \\
\hline $\mathbf{T}$ & XII & 32 \\
\hline B & 1883 & 378 \\
\hline $\mathbf{R}$ & 1882 & $1009-1031$ \\
\hline $\mathbf{R}$ & $1875-76$ & 895 \\
\hline$\$ 2$ & . & 72 et ser. \\
\hline $\mathbf{R}$ & $1875-76$ & 869 \\
\hline B & 1883 & 403 \\
\hline B & $18 \times 3$ & 245 \\
\hline $\mathrm{R}$ & $18 \times 3$ & $114 i-11 i n$ \\
\hline $\mathbf{R}$ & 1881 & $565-587$ \\
\hline $\mathbf{T}$ & X & $11-16$ \\
\hline $\mathbf{T}$ & XI & $5-7$ \\
\hline $\mathbf{R}$ & 188,3 & $1133-11.12$ \\
\hline $\mathrm{R}$ & 1878 & 665 \\
\hline B & 1881 & 449 ot ser. \\
\hline B & 1885 & 290,291 \\
\hline B. & 1883 & 418,419 \\
\hline B & $1886^{\circ}$ & 137 \\
\hline $\mathbf{T}$ & $X \backslash I I$ & 67 \\
\hline B & $188 t$ & 321 \\
\hline $\mathbf{R}$ & $1873-75$ & 516 \\
\hline $\mathrm{R}$ & $1876-77$ & 639 \\
\hline $\mathbf{R}$ & $1876-77$ & 710 \\
\hline $\mathrm{T}$ & XVIII & 20 \\
\hline R & $187^{2}-73$ & 771.772 \\
\hline B & 1883 & 378 \\
\hline $\mathbf{R}$ & $1876-77$ & $7 \times 2$ \\
\hline $\mathbf{R}$ & 1878 & 584 \\
\hline $\mathbf{R}$ & 1879 & 767 et sery. \\
\hline $\mathbf{R}$ & 1878 & $55 \overline{3}-573$ \\
\hline $\mathrm{T}$ & XVII & 25,26 \\
\hline B & 1882 & $17 y-205$ \\
\hline B & 1881 & 73 \\
\hline l' & $1873-75$ & 583 \\
\hline R & 1880 & $509-511$ \\
\hline $\mathrm{T}$ & X V & $79-83$ \\
\hline$T$ & $\mathrm{XII}$ & $5-8$ \\
\hline $\mathrm{R}$ & 1879 & 517 \\
\hline $\mathrm{T}$ & V I & 67 et ser! \\
\hline $\mathrm{T}$ & XXI & 22 et ser. \\
\hline $\mathrm{T}$ & XII & $27-32$ \\
\hline $\mathrm{T}$ & $\mathrm{XX}$ & $2 t$ et ser. \\
\hline B & 1881 & 73 \\
\hline $\mathbf{R}$ & $1872-73$ & $708-709$ \\
\hline $\mathrm{T}$ & XVII & $25-26$ \\
\hline $\boldsymbol{R}$ & $1876-77$ & 533 \\
\hline B & 1886 & $145 \mathrm{et}$ ser. \\
\hline $\mathrm{R}$ & 1878 & 679 \\
\hline$\$ 3$ & $-\ldots$ & 67 et $\Delta 0$. \\
\hline $\mathbf{R}$ & $1872-73$ & 715 \\
\hline $\mathbf{R}$ & $1872-73$ & 731 \\
\hline $\boldsymbol{R}$ & 1878 & 127 \\
\hline
\end{tabular}


BibliograpHy-Continued.

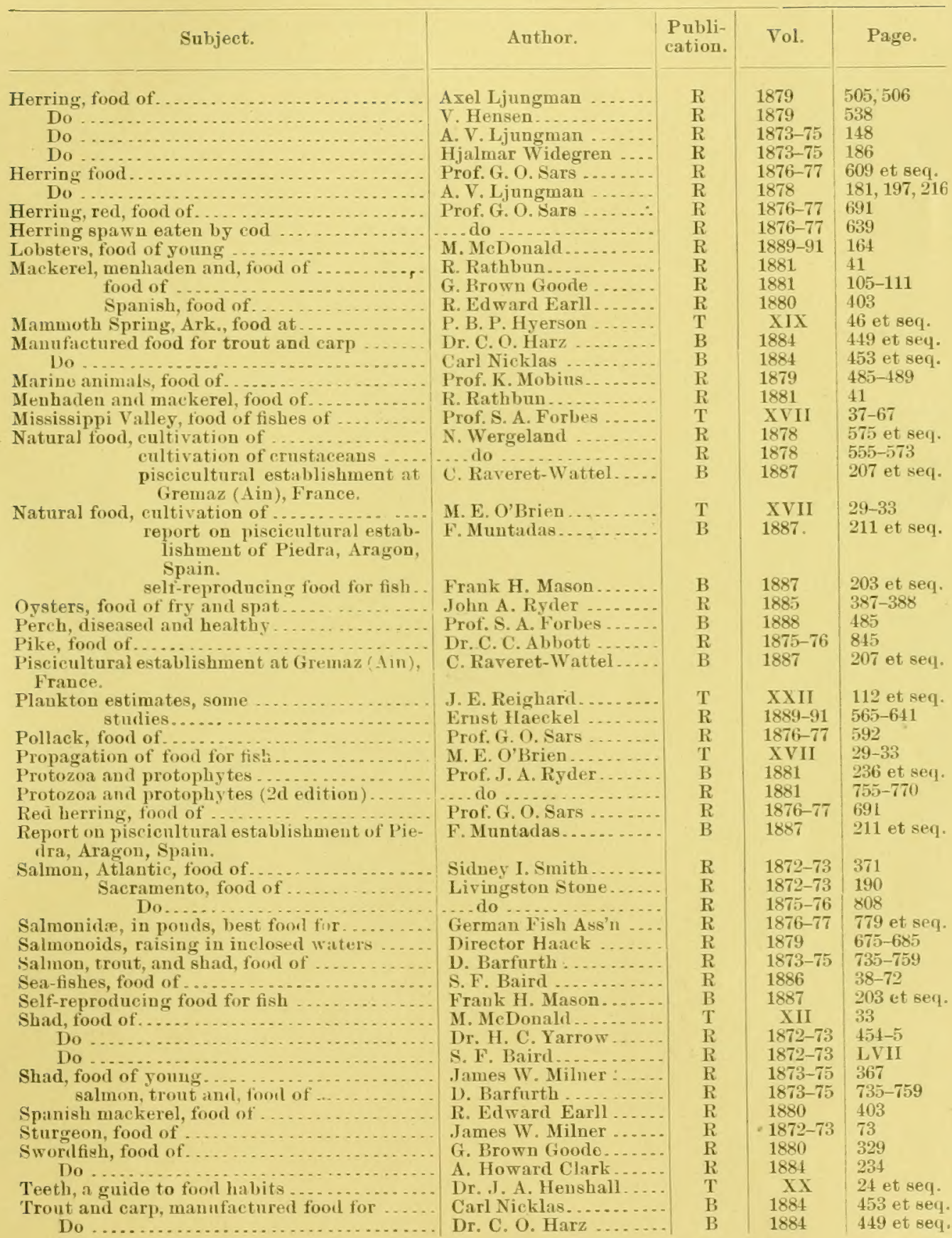


Bublography-Continued.

\begin{tabular}{|c|c|c|c|c|}
\hline Subject. & Author. & $\begin{array}{l}\text { Publi- } \\
\text { cation. }\end{array}$ & Vol. & Page. \\
\hline 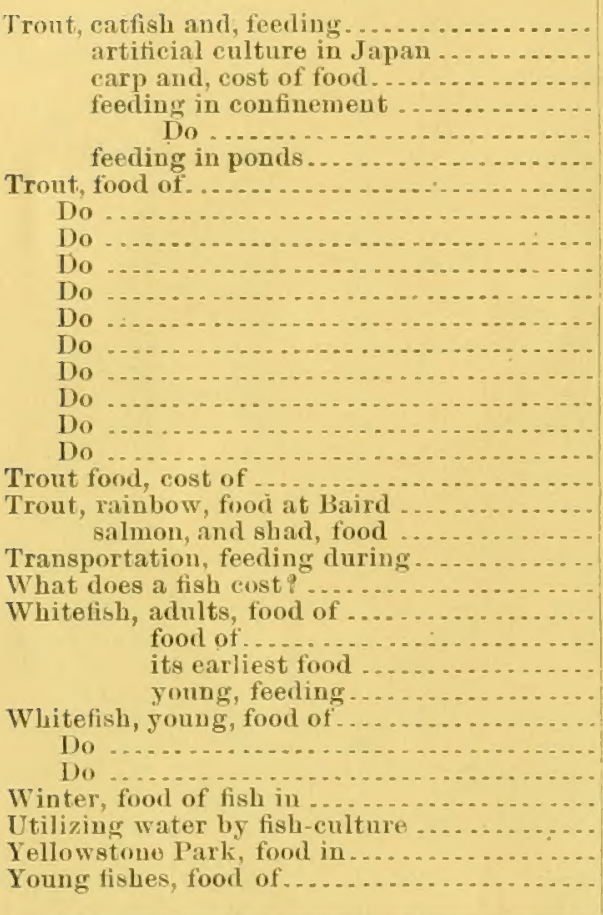 & 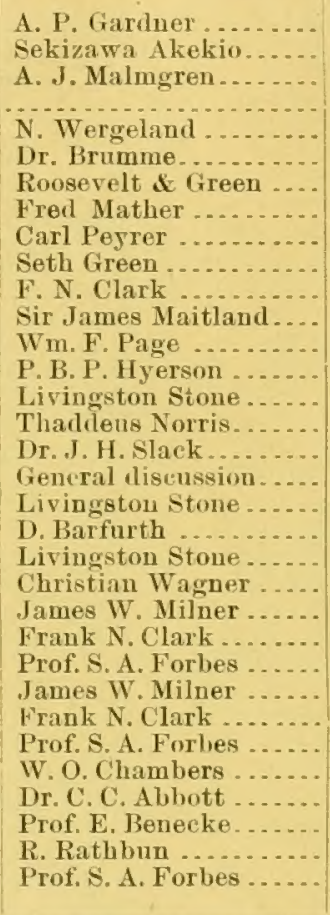 & $\begin{array}{l}\mathrm{B} \\
\mathrm{R} \\
\mathrm{B} \\
\mathrm{T} \\
\mathrm{R} \\
\mathrm{B} \\
\mathrm{T} \\
\mathrm{T} \\
\mathrm{R} \\
\mathrm{S} 5 \\
\mathrm{~T} \\
\mathrm{~S} \\
\mathrm{~T} \\
\mathrm{~T} \\
\mathrm{~S} \\
88 \\
\mathrm{~S} \\
\mathrm{~T} \\
\mathrm{R} \\
\mathrm{R} \\
\mathrm{R} \\
\mathrm{R} \\
\mathrm{R} \\
\mathrm{T} \\
\mathrm{R} \\
\mathrm{R} \\
\mathrm{R} \\
\mathrm{B} \\
\mathrm{B} \\
\mathrm{R} \\
\mathrm{R} \\
\mathrm{R} \\
510\end{array}$ & 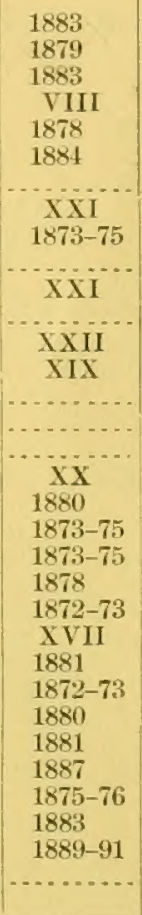 & $\begin{array}{l}418-419 \\
646 \\
378 \\
4-6 \\
554 \\
330-331 \\
79-84,130 \\
87-93 \\
591 \\
37 \text { et seq. } \\
78 \\
61-264 \\
71 \text { et seq. } \\
46 \text { et seq. } \\
228 \text { et seq. } \\
73-68,231 \\
123 \text { et seq. } \\
10 \text { et seq. } \\
618-619 \\
735-759 \\
394 \\
605 \text { et seq. } \\
44 \\
67 \\
771-782 \\
32,57 \\
586 \\
19 \text { et seq. } \\
18 \\
842 \\
1101-1131 \\
138 \\
10-19\end{array}$ \\
\hline
\end{tabular}

The miscellaneous publications referred to in the preceding list are as follows:

6 1. Book of the Black Bass, Dr. J. A. Henshall. 1881. Robert Clark \& Co., Cincinnati.

6. Practical Carp Culture, L. B. Logan. 1888. Yonugstown, Ohio.

6. The Goldfish and Its Culture, Huw" Mulertt. 1883. MeDonali \& Eick, Cincianati, Ohio.

15. Fish Hatehing and Fish Catehing, Seth Green and R. B. Roosevelt. 1879 . Union Advertiser Company, Rochester, N. Y.

65. Trout Culture, Seth Green 1870. Curtis, Moray \& Co, Rochester, $\mathrm{Y}, \mathrm{Y}$.

\$6. History of Howietoun, Sir J. Ramsay Gibson Maitland. 1887. Published by J. R. Gny, secretary Howietoun Fishery. Edinburgh University Press, T. and A. Constable, printers to Her Majesty.

§. Domesticated Trout, Livingston Stone. 1872. Fourth edition. 1891. Cold Spring Tront Ponds, Charlestown, N. H.

58. American Fish Culture, Thaddens Norris. 1868. Porter \& Coates, Philadelphia. Sampson Low, Son \& Co., London.

69. Practical Trout Culture, J. H. Slack. 1872. Ameriean News Company, 39 and 41 Chambers street, New York.

\$10. Proceedings of the Central Fish-Cultural Society. 1880. 
in
in 
